\title{
Comparative Analysis and Survey of Ant Colony Optimization based Rule Miners
}

\author{
${ }^{1,2}$ Zulfiqar Ali \\ ${ }^{1}$ Department of Computer Science, \\ National University of Computer \&Emerging \\ Sciences, Islamabad, 4400, Pakistan \\ ${ }^{2}$ Department of Computer Science \& IT, \\ The University of Lahore, Lahore Campus, \\ $1 \mathrm{Km}$ off defense Road, Pakistan
}

\author{
Waseem Shahzad \\ Department of Computer Science, \\ National University of Computer \&Emerging \\ Sciences, \\ Islamabad, 4400, \\ Pakistan
}

\begin{abstract}
In this research study, we analyze the performance of bio inspired classification approaches by selecting Ant-Miners (Ant-Miner, cAnt_Miner, cAnt_Miner2 and cAnt_MinerPB) for the discovery of classification rules in terms of accuracy, terms per rule, number of rules, running time and model size discovered by the corresponding rule mining algorithm. Classification rule discovery is still a challenging and emerging research problem in the field of data mining and knowledge discovery. Rule based classification has become cutting edge research area due to its importance and popular application areas in the banking, market basket analysis, credit card fraud detection, costumer behaviour, stock market prediction and protein sequence analysis. There are various approaches proposed for the discovery of classification rules like Artificial Neural Networks, Genetic Algorithm, Evolutionary Programming, SVM and Swarm Intelligence. This research study is focused on classification rule discovery by Ant Colony Optimization. For the performance analysis, Myra Tool is used for experiments on the 18 public datasets (available on the UCI repository). Data sets are selected with varying number of instances, number of attributes and number of classes. This research paper also provides focused survey of Ant-Miners for the discovery of classification rules.
\end{abstract}

Keywords-Classification Rule; Ant Colony Optimization; Data Mining; Rule Discovery

\section{INTRODUCTION}

Classification Rule Mining is a Data Mining approach which discovers a set of rules for predicting the class of unseen data. Classification rules are patterns that belong to a specific class. There can be many distinct rules for a class. Every attribute contains a set of distinct domain values. The domain values of attributes are referred to as terms. A classification rule consists of one or more terms, collectively called antecedent, and a class value called consequence. Class based rule mining is hybrid class of rules having classification rule as well as Association rule features which results in class based association rules learning providing associative classification. Associative classification rules are those rules which satisfy the specific support and confidence. The class association rule is shown in (1).

$$
X=>C
$$
label.

Where $\mathrm{X}$ represents a list of items while $\mathrm{C}$ shows the class

There are various approaches used for the classification rule mining and vastly applied ant colony optimization with other techniques and models for searching and optimization purposes. In this study, we are focusing on classification rule mining by using ant colony optimization. This survey study provides variants of ACO based classification rule mining approaches that are known as Ant-Miners in the literature, with their comparative study and analysis. The comprehensive and comparative analysis of ACO based classification rule mining is important to understand the different ant miner algorithms. In this research an effort is made to present comprehensive survey and mathematical analysis of different ant miner algorithms. The focus is on the bio inspired ACO based classification rule mining algorithmic approaches.

There are two major contributions of this research study. First is intensive comparative performance analysis of bio inspired; Ant Colony Optimization based algorithmic approaches exploited for the discovery of classification rule mining and second is focused survey of Ant-Miners for the discovery of classification rules. This paper provides critical and comparative study of various flavors of Ant-Miners and insight of effectiveness of ACO based classification rule mining approaches for the classification purposes. We discuss different parameters and functions exploited in ACO based classification rule mining approaches like heuristic function, term selection probability, and pheromone updating procedure and measuring of rule quality.

The remaining paper consists of the following sections; firstly the section II provides the related work of different approaches exploited for the discovery of classification rule mining, the section III introduces the Ant Colony Optimization, the section IV provides detailed collection of ACO based rule discovery approaches with their critical analysis and comparison, the section $\mathrm{V}$ provides comparative performance analysis of selective Ant-Miners on public data sets. Finally, conclusion and future work is given in the section VI. 


\section{RELATED WORK}

There are various statistical and evolutionary approaches proposed for the classification rule discovery and mining of association rules like artificial neural networks, Support Vector Machine (SVM), Genetic Algorithm (GA) and Swarm Intelligence. However, classification rule mining is still in a stage of exploration and development. In [1] E.Noda et al. applied genetic algorithm for the discovery of interesting prediction rules. D.L.A. Araujo et al. [2] proposed genetic algorithm for the rule mining from the huge databases. In [3] M.V.Fidelis et al. applied the genetic algorithm for the discovery of comprehensible classification rules. Genetic Algorithm is being applied for the discovery of interesting knowledge from a science and technology databases in [3]. In [4] L.Yan, et al. proposed an entropy-based genetic algorithmic approach for the classification rules learning. In [5] X.Zhongyang et al. exploit hybrid genetic algorithmic concept for the mining of classification rules. In [6] X.Shi and H.Lei have proposed Genetic Algorithm-based approach for the discovery of classification rules. In [7] M.Muntean and Valean exploit genetic algorithm for learning classification rules. In [8] Priayanka Sharma and Saroj, have proposed Distributed Genetic Algorithm for the discovery of Classification Rule. In [9] Rekha Dahiya and Anshima Singh provided survey of exploitation of genetic algorithms for the text mining purposes. In [10] Alberto Cano et al. proposed a Genetic Programming Algorithms as classification module in [11].

Artificial Neural Network is also exploited in the field of Data Mining and for the discovery of classification rules. In [12] A.Bharathi and E.Deepankumar have discussed data mining tasks and surveyed main classification techniques, Association Rule Mining, Decision Tree Classification, Neural Networks, Bayesian Classification and Support Vector Machine. In [13] Rasika P Ghom and N.R.Chopde provided application of Neural Networks for the classification tasks in data Mining field. In [14] Chamatkar et al. exploited Artificial Neural Network with other data mining algorithms for the purpose of classification rule mining. Genetic Programming is applied for the discovery of classification rule which results in promising for rule mining tasks. In [15] C.C.Bojarczuk et al. exploited genetic programming for the discovery of comprehensible classification rules. In [16] K.C.Tan et al. applied genetic programming for the mining multiple comprehensible classification rules. In [17] Chi Zhou et al. exploited Gene Expression Programming for the evolution of Classification Rules. In [18] Anubha Sharma and Nirupama Tiwari provided detailed survey of association rule mining algorithms exploiting fussy concepts. In [19], hierarchical multi-label classification rules are mined by using a grammatical evolution algorithm. R.TAlves et al. exploited the strength of artificial immune systems for the knowledge discovery for the hierarchical multi-label classification of protein functions.

There are various survey studies providing useful informative knowledge of algorithmic approaches in Data Mining and classification rule discovery purposes. In [20] K.S.Thirunavukkarasu and S.Sugumaran, provided survey and comparative study of the existing classifiers, Streaming Random Forests , Filter-Based Data Partitioning and Multiple
Classifiers System(MCS) on various data sets, having various classes and instances in the context of running time and error rate of the techniques. In [21] Preeti lata sahu et al. surveyed various data mining approaches for classification of images. In [22] Chaitali Vaghela, Nikita Bhatt and Darshana Mistry provided survey of classification approaches exploited for the Clinical Decision Support systems. In [23] Mihir R Patel and Dipak Dabhi surveyed approaches for the discovery of Association Rule Mining. Swarm Intelligence is cutting edge algorithmic paradigm application in data mining for the purpose of classification rule mining and association rule discovery. Ant Colony Optimization is very effectively and successively applied for the discovery of classification rule mining. In [24] Y.D.Zhang and L.N.Wu have exploited genetic algorithm and ant colony optimization for the building classifier. In [25 ] Sonal P. Rami and Mahesh H. Panchal have studied some dialects of Ant_Miner by using public data for the observation of impact of number of ants on the accuracy rate. In [26] N.N Das and Anjali Saini have survey algorithms for association rule mining and basics terms of Ant Colony Optimization Algorithms are discussed. In [27] Vanaja. S and K. Rameshkumar, analyze performance of classification algorithms on various medical data sets.

The literature survey shows there are a vast variety of applications of ant colony optimization in the field of data mining. R.S. Parpinelli exploited ant behaviour for data mining purposes first time according to the best of our knowledge in [28]. K.Salama and A. A. Freitas [29], exploited ant colony optimization for the learning Bayesian network classifiers which resulted in promising results. On the basis of importance and effectiveness of knowledge discovery from huge data reservoirs, discussions were provided by the A.A Freitas in [30]. In [31], A.A. Freitas provided review of evolutionary algorithms used for the data mining purposes. The study of Ant Colony Algorithms for data classification is given in [32]. The suggestions on improving the interpretability of classification rules in sparse bioinformatics datasets are given in [33]. The performance evaluation measures of hierarchical classifiers are discussed by the E.P.Costa et al. in [34]. Comprehensible classification models are discussed in [35] by the A.A. Freitas. .In [36] T. Karthikeyan and J. Mohana Sundaram have provided the survey of ant colony optimization for association rule mining and comparison between AntMiner and AntMiner+.

This survey paper contributed to research society in two aspects. Firstly by providing larger number of Rule Miners exploiting Ant Colony Optimization particularly and updated related work continued for the discovery of classification rules. Secondly by providing extensive performance analysis of selective Ant Miners by using larger and varying databases which is given in the Section No. 5.

\section{ANT COLONY OPTIMIZATION}

The Ant Colony Optimization is a bio inspired subfield of Swarm Intelligence paradigm for the designing of metaheuristic approaches for optimization problems. The first ACO based algorithm named Ant System, was proposed by Colorni, Dorigo and Maniezzo in early 1990[37]. Swarm Intelligence is a collection of algorithmic approaches inspired by the 
collective intelligence behavior of group of simple agents [38]. The insect's members of swarm such as ants and bees can perform simple tasks individually while their cooperative behavior provides solutions for complex and hard problems. The working procedure of ACO based algorithmic approach models the food searching behavior of real ants. The foraging behavior of real ants for food and convergence of shortest path between food and nest, inspire the Ant Colony Optimization approach for the solution of hard and optimization problems. The pheromone value provides mechanism for the mutual information sharing among the ants that result in cooperative behavior. An artificial ant can be considered as a simple computational agent. In the implementation of artificial ant, probabilistically path selection mechanism is introduced. In basic ACO algorithm pheromone value update and pheromone value evaporation is done by using the mathematical formulae. Generally the pheromone evaporation rate is directly proportional to the length of path. The ACO based metaheuristic approaches are very suitable for the problem scenarios where optimized section is desired. By the literature survey, as shown in the fourth section, ACO is very promising for the discovery of classification rule mining. ACO provides more interesting and useful rule which results in highly predictive and accurate classifiers. The extensive application of ACO for association rule mining purpose is given in the fourth section and results are promising from state-of-the-art approaches.

\section{ACO BASED ClASSIFICATION RULES Mining ALGORITHMS}

\section{A. Ant Miner}

The Rafael S. Parpinelli et al. proposed a nature inspired algorithm for the association rule mining named Ant-Miner in [32]. This approach exploits the real ant food searching behavior for the extraction of classification rules from data. The objective of this approach is to assignment of each case to one class, out of a set of predetermined based on the attributes values for the case. The working mechanism of ant colony optimization based rule mining approach named Ant-Miner can be divided in the five sections. The first section is general description of Ant-Miner, second section is about heuristic function, third section is rule pruning, forth section is pheromone update and last one is usage of discovered rules for new cases classification. Swarm Intelligence based approaches, individuals incrementally constructs a solution for the targeted problem. In the case of associative rule mining, the objective is discovery of classification rule that are exploited by the classifier. The classification rule in the Ant-Miner consists in the given form i.e. IF <term1 AND term2 AND... > THEN $<$ class $>$. In this rule each term is a triple <attribute, operator, value $>$, where value belongs to the attribute domain and operator is relational operator. The Ant-Miner Algorithm operates only on the categorical attributes. During the preprocessing phase continuous attributes are discretized. AntMiner works likely a sequentially covering approach; discovering a list of classification rules by covering almost all training cases. In Ant-Miner, iteration discovers one classification rule and it is added to the discovered rule list. The training cases that are correctly classified by the rule are excluded from the training list. This process continues until the given threshold, called Max_uncoverd_cases. The core operation of Ant-Miner is in which the current ant iteratively adds one term at a time to its current partial rule. In the AntMiner algorithm, the probability of addition of termi,j to the current partial rule is calculated by (2).

$$
P i, j=\frac{\eta_{i j} \tau i j(t)}{\sum_{i=1}^{a} x i \cdot \sum_{j=1}^{b i}\left(\eta_{i j} \tau i j(t)\right)}
$$

Here in (2), is the value of heuristic function for termi,j. The heuristic value shows the relevance of termi,j for classification. The pheromone value associated with termi,j is represented by (t) at iteration $t$. The value of xi shows the status of attribute, used by the ant. Heuristic Function implied in the Ant_Miner is given in (3). In this approach authors use the information gain as heuristic value of a term. In Ant_Miner class is selected after rule construction and default rule is majority class of reaming uncovered samples. Training stops on the basis of max uncovered cases.

$$
H\left(W \mid A_{i}=V_{i},{ }_{j}\right)=-\sum_{w}^{k}\left(P\left(w \mid A_{i}=V_{i}, j\right) \cdot \log _{2} P\left(w \mid A_{i}=V_{i}, j\right)\right)
$$

The equation (4) is used for the calculation of heuristic value by using information gain that is calculated in (3), where $\mathrm{k}$ represents the number of classes. The approach for heuristic function exploited by the Ant-Miner is same as used in decision-tree by differing in the entropy computation for the attributes. In the decision tree approach entropy is computed for an attribute as a whole while in Ant-Miner the entropy is computed for an attribute-value pair only.

$$
\eta_{i, j}=\frac{\log _{2} k-H\left(W \mid A_{i}=V_{i, j}\right)}{\sum_{i=2}^{X} X_{i} \sum_{j=2}^{b_{i}}\left(\log _{2} k-H\left(W \mid A_{i}=V_{i, j}\right)\right)}
$$

Ant-Miner classifier exploits rule pruning approach to remove irrelevant terms that might have been unduly included in the rule. By rule pruning the predictive power of the rule is potentially increased, results in simplicity in the rules and helps to avoiding the over fitting to the training data. The Ant Colony Optimization based approach used the mechanism for the pheromone initialization in the start and later on for the updating the value of pheromone. Here (5) is used for the pheromone initialization and (6) is for the pheromone value updating purposes.

$$
\eta_{i j}(t=0)=\frac{1}{\sum_{i=1}^{n} b_{i}}
$$

Here $(\mathrm{t})$ shows the previous pheromone value at iteration $\mathrm{t}$ and $(t+1)$ is the updated value for the iteration $(t+1)$. The $Q$ is the quality of the rule which is calculated by (7).

$$
\eta_{i, j}(t+1)=\eta_{i, j}(t)+\eta_{i, j}(t) \cdot Q, \forall i, j \in R
$$


The rule quality is evaluated by (7). Where TP, TN, FP and FN stands for true positive, true negative, false positive and False negative respectively.

$$
Q=\frac{T P}{T P+F P} \cdot \frac{T N}{F P+T N}
$$

The performance of the Ant-Miner is promising with CN2. The predictive accuracy of the proposed approach is competitive with CN2 and also rules discovered by Ant-Miner are smaller than CN2.

\section{B. Ant Miner2}

Bo Liul et al. [39], proposed an enhancement in the classification rule mining approach “Ant-Miner” exploiting bio inspired Ant Colony Optimization. The enhance version of Ant-Miner, named Ant-Miner2, exploits density estimation as a heuristic function instead of information gain used by AntMiner. In terms of computation Ant-Miner2 is less expensive than the original Ant-Miner. Ant-Miner2 is based on simple division instead of the logarithm as in Ant-Miner. In AntMiner2, the pheromone initialization, pheromone updating and rule quality is measured similarly as in the Ant-Miner, by using (5), (6) and (7) respectively. The main difference between Ant-

Miner and Ant-Miner2 is in heuristic value $\eta_{i, j}$ calculation. The heuristic function used in Ant-Miner2 is given in the table No.1. The proposed enhancement was compared with AntMiner by using UCI data set. Both the approaches performance was same in the context of accuracy and number of rules.

\section{Ant Miner3}

Bo Liu1et al. proposed improvements in the classification rule mining ACO based algorithm named Ant-Miner. New version of the Ant-Miner is namely, Ant-Miner3 [40], uses a different pheromone updating strategy and state transition rule which results in improvements in terms of accuracy of rule lists. In the proposed classification rule mining approach (AntMiner3), authors incorporated a tuneable stochastic element which cases balance between exploitation and exploration in its operation during the construction of a rule. In Ant-Miner3, the behaviour of real ants is more accurately modelled which provides a greater diversity in path choices, assists in finding an optimal rule. The quality of a rule and the accuracy of rule sets are improved by introducing a new pheromone updating rule. The working procedure of Ant-Miner3 differs from AntMinere2 in terms of pheromone updating method. After construction of rule, pheromone value associated with each term is updated according to the relation that is given in the Table I.In Ant-Miner3, the larger value of $p$ indicates a fast evaporation and vice versa. The value of $p$ used in experiments is fixed at 0.1 . In equation (6), $Q$ represents the quality of rule constructed. The quality of rule $Q$ is calculated by using (7). This research work suggests that Ant-Miner3 has a number of parameters that requires optimization. In AntMiner3 all rules are pruned and pheromone matrix is symmetric.

\section{AntMiner+}

David Martens et al. [41], proposed a Max-Min Ant System based algorithm known as Ant-Miner+. The new classification rule mining approach is based on the bio inspired Ant-Miner. The main differences between proposed approach and previously defined AntMiner versions are exploitation of better forming, MAX-MIN, Ant System, augmented environment and search space for the ant's walk. The proposed approach AntMiner+, is capable to handle multiclass problems and ability to include interval rules in the rule list. For the system parameter setting, there is automated and dynamic manner is introduced in the Ant-Miner+. AntMiner+ has early stopping criterion. The Ant-Miner+ uses different formulae for the pheromone initialization initially. The heuristic value, probability of term selection, pheromone updating and rule quality measuring relations are given in the Table I. The proposed approach (AntMiner+) is compared with state-of-the-art classification approaches such as C4.5, RIPPER and SVM in a benchmark study. The results are promising in terms of accuracy and time complexity.

\section{E. CAnt Miner}

Abdul Rauf Baig et al. proposed improvements in the CAntMiner algorithm in [42], that provided promising classification rule discover in medical data sets. The suggested improvements include use of novel heuristic function and reported its application to medical datasets. The CAntMiner technique focused primarily to categorical data and real valued attributes are discretized. In this research authors proposed some modification for the CAntMiner algorithm like finding discretization intervals and discovery of unordered rule set. In CAntMiner, domain knowledge can also be incorporated even after the delivery of its rule set. It facilitated in rule generalization and made more specific addition of new rules. The performance of CAntMiner is compared with ten well known classification algorithms including three ACO based. The experimental results of CAntMiner are more promising than that of compared algorithms in terms of accuracy rate. In CAntMiner, pheromone initialization, term selection probability, pheromone updating and quality of rule computing relationship are given in the Table I which is depicting the comparison of Ant-Miner variants.

\section{F. ACO-AC}

Waseem Shahzad and Abdul Rauf Baig proposed a new bio inspired hybrid classification approach, named ACO-AC in [43]. ACO-AC algorithm exploited hybrid approach by combining the idea of association rules mining and supervised classification. The idea of hybridization in ACO-AC, classification is integrated with association rule mining which enables discovery of high quality rules which results in improvement in the performance of classifier. In this approach ant colony optimization is applied to discover more appropriate subset of class association rules instead of exhaustively searching for all possible rules. The strong association rules based on confidence and support are discovered and then used for classification of unseen data. The ACO-AC, mines rules distributed manner of each class. This approach shows promising results on comparison with other state-of-the-art classification algorithms. ACO-AC is more accurate and achieves higher accuracy rates with respect to other classification approaches. 


\section{G. AntMiner-C}

Abdul Rauf Baig and Waseem Shahzad proposed a new bio inspired, classification approach, named AntMiner-C in [44]. The focus of this research is on the discovery of rules for the classification task using supervised training data. The main feature of AntMiner-C is a heuristic function based correlation among the attributes. The other prominent contribution of this research is assignment of class labels to the rules prior to their discovery. It results in dynamically stoppage in the addition of terms in rule's antecedent part as well as a strategy for pruning redundant rules from the rule set. The authors have compared the proposed approach with the original AntMiner algorithm, decision tree builder C4.5, Ripper, logistic regression technique, and a SVM by using common data sets. Experimental results shows that proposed algorithm, AntMiner-C are promising in terms of accuracy.

\section{H. cAnt-Miner}

Fernando E. B. Otero et al. proposed a classification rule mining ACO based algorithm which introduced improvements in Ant-Miner for coping with continuous attributes, named cAnt-Miner [45]. The proposed approach, cAnt-Miner exploits an entropy-based discretization technique during the rule construction process which enables the cAnt-Miner to cope with continuous attributes. The discretization performed in preprocessing step, employed in Ant-Miner is substituted with dynamic discretization method in cAnt-Miner by creating discrete intervals for continuous attributes "on-the-fly", exploiting all continuous attributes information. The new feature, continuous attributes "on-the-fly", incorporation in cAnt-Miner has improved predictive accuracy while discretization method in a pre-processing step used in AntMiner, can lead to loss of predictive power due to the limitation in information available to the classification algorithm. The entropy for the attribute-value pair is computed similarly as in the basic Ant-Miner algorithm.

The computational complexity of the cAnt-Miner can be assisted by dividing threshold value finding process into two steps; 1 ) the sorting process of continuous attribute values that help in the computation of the number of examples belonging to each candidate interval has time complexity O (nlogn); 2) while candidate threshold values evaluation phase has the complexity $\mathrm{O}(\mathrm{n})$. Here $\mathrm{n}$ shows the candidate values to be evaluated. For the performance evaluation of the proposed cAnt-Miner algorithm, author's selected eight standard datasets from the UCI Irvine machine learning repository included at least one continuous attribute value. The experimental results showed that, in terms of predictive accuracy, cAnt-Miner is significantly more accurate than Ant-Miner in the hepatitis and glass dataset .The average result comparison with Ant-Miner are promising for cAnt-Miner in terms of predictive accuracy and simplicity of the discovered rule lists. In this research work, author also suggested extension and improvements in the entropy based discretization method, in which creation of intervals can be allowed with lower and upper bound values in the form of $V_{\text {lower }} \leq$ attribute $\leq V_{\text {upper }}$.

\section{ACO-Miner}

Peng Jin et al. proposed a new classification rule mining algorithm named ACO-Miner in [46]. ACO-Miner is enhanced version of Ant-Miner that is based on bio inspired concept Ant Colony Optimization. In the ACO-Miner, author incorporated new feature that are, the multi-population parallel strategy, the cost-based discretization methodology and adjustment of parameters step by step. In ACO-Miner, ant colony is divided into some, parallel and separately running, populations. Here each population has same amount of ants, search rules and list of pheromone values. After evaluation, best rule is included into the final discovered rule list. The minimum number of cases covered per rule in ACO-Miner is variable; initially its value is set bigger and smaller at the late phase. The bigger value leads to the reduction in computing time while smaller values causes the discovery of new rules effectively. ACOMiner has five user-defined parameters that are given in [46]. The performance of the proposed approach (ACO-Miner) is evaluated by applying SIMiner, a swarm intelligence based, self-development data mining software system. The standard data sets are used from UCI Repository on Machine Learning. The proposed algorithm (ACO-Miner) is compared with AntMiner and CN2. The results are promising for ACO-Miner in terms of predictive accuracy and simplicity of rules than AntMiner and CN2 algorithms.

Prakash S. Shelokar et al. [47] applied the Ant Colony Optimization based classification approach for the prediction of environmental factors i.e. temperature, water activity, $\mathrm{pH}$ which highly effects the growth of microorganism. The bio inspired ACO algorithm is exploited for the learning of classification rules for the prediction of bacterial growth in data pertaining to pathogenic Escherichia coli R31. The experimental results of ACO based Classifier System are promising with respect to $\mathrm{NN}$ and C4.5.

Namita Shrivastava and Vineet Richariya exploited the strong foraging behaviour of ants with classification algorithms for the mining of classification rules in the domain of Intrusion Detection System. For the detection and prediction of specific class of attacks, ACO based Intrusion Detection approaches are providing promising results. In this research work ACO is used to find efficiently the values of detection rates and false alarms rate. The experiments performed on the benchmark dataset, KDD-Cup99, are promising on the comparison of state-of-theart algorithms.

All the variants of Ant Colony Optimization based data mining approaches that are known as Ant-Miners have common framework that consists of pheromone initialization, heuristic function value, selection probability, relation for evolution of rule quality discovered by the ants and the mechanism for the pheromone value updates of the more interesting and valuable rules. With critically observations on the Table I it concluded that mostly variants of Ant-Miner proposed variation in one of the stated basic components of the 
TABLE I. COMPARISON OF VARIANTS OF ANT MINERS

\begin{tabular}{|c|c|c|c|c|c|}
\hline $\begin{array}{c}\text { Classifi } \\
\text { ers }\end{array}$ & Heuristic Function & $\begin{array}{l}\text { Initial Pheromone } \\
\text { Value }\end{array}$ & Selection Probability & Rule Quality & Pheromone Update \\
\hline $\begin{array}{c}\text { Ant } \\
\text { Miner }\end{array}$ & $\eta_{i, j}=\frac{\log _{2} k-H\left(W \mid A_{i}=V_{i, j}\right)}{\sum_{i=2}^{X} X_{i} \sum_{j=2}^{b_{i}}\left(\log _{2} k-H\left(W \mid A_{i}=V_{i, j}\right)\right)}$ & $\eta_{i j}(t=0)=\frac{1}{\sum_{i=1}^{n} b_{i}}$ & $P i, j=\frac{\eta_{i j} \tau i j(t)}{\sum_{i=1}^{a} x i \cdot \sum_{j=1}^{b i}\left(\eta_{i j} \tau i j(t)\right)}$ & $Q=\frac{T P}{T P+F P} \cdot \frac{T N}{F P+T N}$ & $\eta_{i, j}(t+1)=\eta_{i, j}(t)+\eta_{i, j}(t) \cdot Q, \forall i, j \in R$ \\
\hline $\begin{array}{c}\text { Ant } \\
\text { Miner2 }\end{array}$ & $\eta_{i, j}=\frac{\text { Marity }_{-} \text {Class }_{i j}}{T_{i j}}$ & $\eta_{i j}(t=0)=\frac{1}{\sum_{i=1}^{n} b_{i}}$ & $P i, j=\frac{\eta_{i j} \tau i j(t)}{\sum_{i=1}^{a} x i \cdot \sum_{j=1}^{b i}\left(\eta_{i j} \tau i j(t)\right.}$ & $Q=\frac{T P}{T P+F P} \cdot \frac{T N}{F P+T N}$ & $\eta_{i, j}(t+1)=\eta_{i, j}(t)+\eta_{i, j}(t) \cdot Q, \forall i, j \in R$ \\
\hline $\begin{array}{c}\text { Ant } \\
\text { Miner3 }\end{array}$ & $\eta_{i, j}=\frac{\text { Marity }_{-} \text {Class }_{i j}}{T_{i j}}$ & $\eta_{i j}(t=0)=\frac{1}{\sum_{i=1}^{n} b_{i}}$ & $P i, j=\frac{\eta_{i j} \tau i j(t)}{\sum_{i=1}^{a} x i \cdot \sum_{j=1}^{b i}\left(\eta_{i j} \tau i j(t)\right)}$ & $Q=\frac{T P}{T P+F P} \cdot \frac{T N}{F P+T N}$ & $\begin{aligned} \eta_{i, j}(t+1)= & (1-\rho) \eta_{i, j}(t-1)+ \\
& \left(1-\frac{1}{1+Q}\right) \eta_{i, j}(t-1)\end{aligned}$ \\
\hline $\begin{array}{c}\text { Ant } \\
\text { Miner+ }\end{array}$ & $\eta_{i, j}=\frac{T_{i j} \& \text { Class }=\text { Marity } \_ \text {Class } T_{i j}}{T_{i j}}$ & $\tau \max$ & 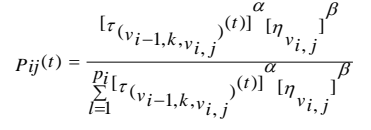 & $Q=\frac{T P}{\text { Comvered }} \cdot \frac{T N}{N}$ & $\tau_{\left(v_{i, j}, v_{i+1}, k\right)}(t+1)=\rho \cdot \tau_{\left(v_{i, j}, v_{i+1}, k\right)}(t+1)+\frac{Q_{b e s t}^{+}}{10}$ \\
\hline $\begin{array}{l}\text { CAntM } \\
\text { iner }\end{array}$ & $\eta_{i, j}=$ Correct_Coverege $_{i j} \frac{\left.\right|_{\text {term }_{i j}}, K \mid}{\text { total }_{-} \text {term }_{j}}$ & $\eta_{i j}(t=0)=\frac{1}{\sum_{i=1}^{n} b_{i}}$ & $P i, j=\frac{\eta_{i j(s) \cdot \tau i j(t)}}{\sum_{i=1}^{a} x i \cdot \sum_{j=1}^{b i}\left\{\eta_{i j(s)} \tau i j(t)\right\}}$ & $Q=\frac{T P}{\text { Comvered }} \cdot \frac{T N}{N}$ & $\begin{array}{r}\eta_{i, j}(t+1)=(1-\rho) \cdot \tau i, j(t), \quad \text { whenterm selected } \\
\begin{aligned} \tau i, j(t+1)=\tau i, j(t)+\left(1-\frac{1}{1+Q}\right) \cdot \tau i, j \\
\text { whenterm not selected }\end{aligned}\end{array}$ \\
\hline $\begin{array}{l}\text { AntMin } \\
\text { er-C }\end{array}$ & 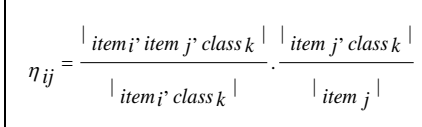 & $\eta_{i j}(t=1)=\frac{1}{\sum_{n=1}^{a} x_{n \cdot b_{n}}}$ & $P i, j=\frac{\eta_{i j}^{\alpha}(s) \cdot \tau_{j i}^{\beta}(t)}{\sum_{i=1}^{\text {total }}{ }^{\text {terms }}{ }_{x j}\left\{\eta_{i j}^{\alpha}(s) \cdot \tau_{j i}^{\beta}(t)\right\}}$ & $Q=\frac{T P}{\text { Comvered }} \cdot \frac{T N}{N}$ & $\tau i j(t+1)=\tau_{i j}(t)(1-\rho)+\left(1-\frac{1}{1+Q}\right) \cdot \tau i j(t)$ \\
\hline $\begin{array}{l}\text { ACO- } \\
\text { AC }\end{array}$ & $\eta_{i, j}=$ Correct_Coverege $_{i j} \frac{\left.\right|_{\text {term }_{i j}, K \mid}}{\text { total }_{-} \text {term }_{j}}$ & $\eta_{i j}(t=1)=\frac{1}{\sum_{i=1}^{a} b_{i}}$ &  & $Q=\frac{T P}{\text { Covered }}$ & $\tau i j(g+1)=\tau_{i j}(g)(1-\rho)+\left(1-\frac{1}{1+Q}\right) \cdot \tau i j(g)$ \\
\hline
\end{tabular}

Ant-Miner proposed in [32]. In Ant-Miner2 [39], new heuristic function is proposed i.e. is given in the Table I and initial pheromone initialization, measurement of rule quality and pheromone value update is done likely to the Ant-Miner [32]. In Ant-Miner3 new pheromone update mechanism is proposed which resulted promising results. The Ant-Miner+ [41], variant of Ant-Miner introduced new relations for initial pheromone value, rule quality evaluation and pheromone value update. New pheromone value is boosted directly to the quality of the rule. The CAnt-Miner [42] differs in heuristic function, and pheromone update value. There are separate pheromone update relations in the case of term selection or rejection. These changes produced competitive results with respect to other state-of-the-art classification rule mining approaches. The authors proposed new relation for the initial pheromone value for the terms in the rule as well as new heuristic function for the selection of new terms for the next generation.

The ACO-AC flavor of ACO based mining approach for the discovery of associative rule exploits new mechanism for the evaluation of rule quality and heuristic function for the selection of new terms in antecedent. In the given variants of Ant-Miner for the classification rule discovery, is focused on the selection of heuristic function and evaluation of the quality of the rules that are mined. Although various mining approaches are proposed but there is still more requirements of new Ant-Miner variants that tackle discrete values as well as 
continues data sets effectively and efficiently. This survey study concludes that Swarm Intelligence based classification rule discovery approaches (PSO, ACO) are more promising as compared to the state-of-the-art techniques like artificial neural networks, SVM and genetic algorithm.

In section $\mathrm{V}$, detailed performance analysis of the selective Ant-Miners variants is given by using Myra on public databases obtained from UCI Machine Learning Repository.

\section{PERFORMANCE ANALYSIS OF ANT-Miners}

This section provides intensive comparative performance analysis of bio inspired; Ant Colony Optimization based algorithmic approaches exploited for the discovery of classification rule mining. In [25], Sonal P. Rami and Mahesh $\mathrm{H}$. Panchal have given analysis of few ant-miners on few data sets by varying input parameters. This research study provides more intensive and detailed comparative performance analysis of variants of Ant-Miners on the public data sets. This section gives detailed performance comparison of bio inspired AntMiner dialects (Ant-Miner, cAnt-Miner, cAnt-Miner2 and cAnt-MinerPB) on the public domain data sets( available at UCI repository) [48] in terms of accuracy, terms per rule, number of rules, model size and execution time by using the Myra Tool [49]. Myra is a cross-platform Ant Colony Optimization framework written in Java. It includes the implementation of Ant-Miner dialects. We have selected AntMiner, cAnt-Miner, cAnt-Miner2 and cAnt-MinerPB for the comparative performance on the selective public data sets. The database selection considers the size of data base and number of classes. The execution of all the algorithms is done on the Intel(R) Core(TM) i5-2415M CPU @ 2.30GHz with 4.00 GB machine and 64-bit Operating System. Table III shows the detailed performance analysis of the stated dialects of AntMiners by using the standard parameters set in the Myra tool for the corresponding algorithms. The table No.3 shows the accuracy in percentage with standard deviation and time is in second.

\section{J. Data Sets Description}

The Table II shows the description of data sets which are used for the performance evaluation of the bio inspired rule discovering algorithmic dialects (Ant_Miner, cAnt_Miner, cAnt_Miner2 and cAnt_MinerPB) with information with number of instances, number of attributes and number of classes of the various public data sets that are downloaded from the UCI website. Here 18 data sets are selected with different \#instances, \#attributes and \#classes for the performance analysis with variety of number of instances, attributes and classes.

TABLE II. DATA SETS DESCRIPTION

\begin{tabular}{|l|c|c|c|l|c|c|c|}
\hline Dataset & \#Instances & \#Attributes & \#Classes & \multicolumn{1}{|c|}{ Dataset } & \#Instances & \#Attributes & \#Classes \\
\hline Anneal & 718 & 38 & 5 & House-Vote & 391 & 16 & 2 \\
\hline Australian & 621 & 14 & 2 & Hepatitis & 139 & 19 & 2 \\
\hline Backup & 276 & 35 & 4 & Hypothyroid & 3163 & 26 & 2 \\
\hline Breast & 699 & 10 & 2 & Ionosphere & 351 & 34 & 2 \\
\hline Bupa & 345 & 6 & 2 & New-Thyroid & 193 & 5 & 3 \\
\hline Crx & 621 & 15 & 2 & $\begin{array}{l}\text { Soybean- } \\
\text { Large }\end{array}$ & 276 & 35 & 4 \\
\hline Diabetes & 691 & 8 & 2 & $\begin{array}{l}\text { Soybean- } \\
\text { Small }\end{array}$ & 42 & 21 & 4 \\
\hline German & 900 & 20 & 2 & Tic-Tac-Toe & 862 & 9 & 2 \\
\hline $\begin{array}{l}\text { Horse- } \\
\text { Colic }\end{array}$ & 270 & 27 & 2 & Wime & 160 & 13 & 3 \\
\hline
\end{tabular}

K. Comparative Performance Analysis of Ant-Miners

The Table III provides the collective comparative performance analysis of the under focused study, the rule discovering ACO based algorithms in terms of accuracy, terms per rules, number of rules, time and model size generated by the corresponding approaches. 
TABLE III. COMParative PERformance ANALysis OF ANT-Miners

\begin{tabular}{|c|c|c|c|c|c|c|c|c|c|c|}
\hline & \multicolumn{5}{|c|}{ Ant_Miner } & \multicolumn{5}{|c|}{ cAnt_Miner } \\
\hline Data Sets & Accuracy & $\begin{array}{c}\text { Terms } \\
\text { per rule }\end{array}$ & $\begin{array}{c}\text { Number } \\
\text { of rules }\end{array}$ & $\begin{array}{l}\text { Time } \\
\text { (Sec) }\end{array}$ & $\begin{array}{c}\text { Model } \\
\text { size }\end{array}$ & Accuracy & $\begin{array}{c}\text { Terms } \\
\text { per rule }\end{array}$ & $\begin{array}{c}\text { Number of } \\
\text { rules }\end{array}$ & $\begin{array}{l}\text { Time } \\
\text { (Sec) }\end{array}$ & Model size \\
\hline Anneal & $\begin{array}{l}86.468 \\
\pm 0.578 \\
\end{array}$ & $\begin{array}{c}1.836 \\
\pm 0.030 \\
\end{array}$ & $\begin{array}{l}12.300 \\
\pm 0.260 \\
\end{array}$ & 89 & $\begin{array}{l}22.600 \\
\pm 0.702 \\
\end{array}$ & $\begin{array}{l}85.884 \\
\pm 0.827 \\
\end{array}$ & $\begin{array}{c}2.031 \\
\pm 0.043 \\
\end{array}$ & $\begin{array}{l}10.980 \\
\pm 0.208 \\
\end{array}$ & 858 & $\begin{array}{l}22.260 \\
\pm 0.368 \\
\end{array}$ \\
\hline Australian & $\begin{array}{r}85.652 \\
\pm 1.694 \\
\end{array}$ & $\begin{array}{c}1.404 \\
\pm 0.060 \\
\end{array}$ & $\begin{array}{c}8.300 \\
\pm 0.213 \\
\end{array}$ & 33 & $\begin{array}{r}11.700 \\
\pm 0.684 \\
\end{array}$ & $\begin{array}{r}85.362 \\
\pm 1.172 \\
\end{array}$ & $\begin{array}{c}1.474 \\
\pm 0.041 \\
\end{array}$ & $\begin{array}{c}6.600 \\
\pm 0.163 \\
\end{array}$ & 40 & $\begin{array}{c}9.700 \\
\pm 0.260 \\
\end{array}$ \\
\hline Backup & $\begin{array}{l}97.699 \\
\pm 0.864 \\
\end{array}$ & $\begin{array}{c}1.097 \\
\pm 0.053 \\
\end{array}$ & $\begin{array}{c}5.400 \\
\pm 0.163 \\
\end{array}$ & 14 & $\begin{array}{c}5.900 \\
\pm 0.277 \\
\end{array}$ & $\begin{array}{l}94.129 \\
\pm 0.951 \\
\end{array}$ & $\begin{array}{c}1.180 \\
\pm 0.020 \\
\end{array}$ & $\begin{array}{c}5.000 \\
\pm 0.000 \\
\end{array}$ & 325 & $\begin{array}{c}5.900 \\
\pm 0.100 \\
\end{array}$ \\
\hline Breast & $\begin{array}{r}92.841 \\
\pm 1.154 \\
\end{array}$ & $\begin{array}{c}1.060 \\
\pm 0.010\end{array}$ & $\begin{array}{r}13.500 \\
\pm 0.342 \\
\end{array}$ & 28 & $\begin{array}{l}14.300 \\
\pm 0.367 \\
\end{array}$ & $\begin{array}{l}92.694 \\
\pm 0.908\end{array}$ & $\begin{array}{c}0.950 \\
\pm 0.017\end{array}$ & $\begin{array}{l}10.300 \\
\pm 0.153\end{array}$ & 30 & $\begin{array}{c}9.800 \\
\pm 0.291\end{array}$ \\
\hline Bupa & $\begin{array}{l}61.992 \\
\pm 1.620\end{array}$ & $\begin{array}{c}1.010 \\
\pm 0.010\end{array}$ & $\begin{array}{c}9.100 \\
\pm 0.100\end{array}$ & 27 & $\begin{array}{c}9.200 \\
\pm 0.200\end{array}$ & $\begin{array}{l}65.193 \\
\pm 1.713 \\
\end{array}$ & $\begin{array}{c}1.000 \\
\pm 0.000\end{array}$ & $\begin{array}{c}7.400 \\
\pm 0.163 \\
\end{array}$ & 23 & $\begin{array}{c}7.400 \\
\pm 0.163\end{array}$ \\
\hline Crx & $\begin{array}{r}85.942 \\
\pm 1.223 \\
\end{array}$ & $\begin{array}{c}1.448 \\
\pm 0.051\end{array}$ & $\begin{array}{c}7.800 \\
\pm 0.249 \\
\end{array}$ & 40 & $\begin{array}{l}11.200 \\
\pm 0.249 \\
\end{array}$ & $\begin{array}{l}85.362 \\
\pm 1.408 \\
\end{array}$ & $\begin{array}{c}1.507 \\
\pm 0.058 \\
\end{array}$ & $\begin{array}{c}6.300 \\
\pm 0.260 \\
\end{array}$ & 52 & $\begin{array}{c}9.500 \\
\pm 0.543 \\
\end{array}$ \\
\hline Diabetes & $\begin{array}{l}69.152 \\
\pm 1.417\end{array}$ & $\begin{array}{c}1.724 \\
\pm 0.046\end{array}$ & $\begin{array}{c}9.200 \\
\pm 0.200\end{array}$ & 28 & $\begin{array}{l}15.900 \\
\pm 0.640\end{array}$ & $\begin{array}{l}68.612 \\
\pm 1.510 \\
\end{array}$ & $\begin{array}{c}1.610 \\
\pm 0.039\end{array}$ & $\begin{array}{c}8.500 \\
\pm 0.224\end{array}$ & 23 & $\begin{array}{l}13.700 \\
\pm 0.539\end{array}$ \\
\hline German & $\begin{array}{l}70.300 \\
\pm 1.202 \\
\end{array}$ & $\begin{array}{c}1.441 \\
\pm 0.039 \\
\end{array}$ & $\begin{array}{c}9.800 \\
\pm 0.389 \\
\end{array}$ & 57 & $\begin{array}{l}14.100 \\
\pm 0.640 \\
\end{array}$ & $\begin{array}{l}69.000 \\
\pm 1.498 \\
\end{array}$ & $\begin{array}{c}1.510 \\
\pm 0.065 \\
\end{array}$ & $\begin{array}{c}8.800 \\
\pm 0.133 \\
\end{array}$ & 104 & $\begin{array}{l}13.300 \\
\pm 0.651 \\
\end{array}$ \\
\hline Hepatitis & $\begin{array}{r}67.167 \\
\pm 3.921 \\
\end{array}$ & $\begin{array}{c}2.048 \\
\pm 0.103 \\
\end{array}$ & $\begin{array}{c}5.500 \\
\pm 0.269 \\
\end{array}$ & 42 & $\begin{array}{r}11.200 \\
\pm 0.712 \\
\end{array}$ & $\begin{array}{r}60.000 \\
\pm 3.776 \\
\end{array}$ & $\begin{array}{c}1.972 \\
\pm 0.062 \\
\end{array}$ & $\begin{array}{c}4.900 \\
\pm 0.277 \\
\end{array}$ & 62 & $\begin{array}{r}9.600 \\
\pm 0.521 \\
\end{array}$ \\
\hline Horse-Colic & $\begin{array}{r}87.333 \\
\pm 1.388 \\
\end{array}$ & $\begin{array}{c}1.095 \\
\pm 0.039 \\
\end{array}$ & $\begin{array}{c}4.400 \\
\pm 0.221 \\
\end{array}$ & 12 & $\begin{array}{c}4.800 \\
\pm 0.249 \\
\end{array}$ & $\begin{array}{r}86.333 \\
\pm 1.822 \\
\end{array}$ & $\begin{array}{c}1.090 \\
\pm 0.049 \\
\end{array}$ & $\begin{array}{c}5.200 \\
\pm 0.133 \\
\end{array}$ & 32 & $\begin{array}{c}5.700 \\
\pm 0.367 \\
\end{array}$ \\
\hline House-Vote & $\begin{array}{l}95.624 \\
\pm 1.207 \\
\end{array}$ & $\begin{array}{c}0.905 \\
\pm 0.058\end{array}$ & $\begin{array}{c}5.300 \\
\pm 0.300 \\
\end{array}$ & 15 & $\begin{array}{c}4.900 \\
\pm 0.526 \\
\end{array}$ & $\begin{array}{l}95.867 \\
\pm 0.949 \\
\end{array}$ & $\begin{array}{c}0.782 \\
\pm 0.014 \\
\end{array}$ & $\begin{array}{c}4.700 \\
\pm 0.213 \\
\end{array}$ & 7 & $\begin{array}{c}3.700 \\
\pm 0.213 \\
\end{array}$ \\
\hline Hypothyroid & $\begin{array}{r}67.708 \\
\pm 3.105 \\
\end{array}$ & $\begin{array}{c}2.020 \\
\pm 0.059 \\
\end{array}$ & $\begin{array}{c}5.600 \\
\pm 0.163 \\
\end{array}$ & 14 & $\begin{array}{r}11.300 \\
\pm 0.448 \\
\end{array}$ & $\begin{array}{r}64.583 \\
\pm 3.991 \\
\end{array}$ & $\begin{array}{c}2.105 \\
\pm 0.081 \\
\end{array}$ & $\begin{array}{c}4.900 \\
\pm 0.100 \\
\end{array}$ & 16 & $\begin{array}{r}10.300 \\
\pm 0.423 \\
\end{array}$ \\
\hline Ionosphere & $\begin{array}{l}82.643 \\
\pm 1.580\end{array}$ & $\begin{array}{c}0.980 \\
\pm 0.014\end{array}$ & $\begin{array}{l}10.100 \\
\pm 0.233\end{array}$ & 376 & $\begin{array}{c}9.900 \\
\pm 0.277\end{array}$ & $\begin{array}{l}84.056 \\
\pm 1.804\end{array}$ & $\begin{array}{c}1.000 \\
\pm 0.000\end{array}$ & $\begin{array}{c}7.900 \\
\pm 0.100\end{array}$ & 568 & $\begin{array}{c}7.900 \\
\pm 0.100\end{array}$ \\
\hline $\begin{array}{c}\text { New- } \\
\text { Thyroid }\end{array}$ & $\begin{array}{l}86.039 \\
\pm 3.129 \\
\end{array}$ & $\begin{array}{c}1.240 \\
\pm 0.098\end{array}$ & $\begin{array}{c}5.300 \\
\pm 0.153\end{array}$ & 4 & $\begin{array}{c}6.500 \\
\pm 0.428\end{array}$ & $\begin{array}{l}84.978 \\
\pm 2.681 \\
\end{array}$ & $\begin{array}{c}1.300 \\
\pm 0.100\end{array}$ & $\begin{array}{c}5.000 \\
\pm 0.000\end{array}$ & 3 & $\begin{array}{c}6.500 \\
\pm 0.500\end{array}$ \\
\hline $\begin{array}{l}\text { Soybean- } \\
\text { Large }\end{array}$ & $\begin{array}{c}97.720 \\
\pm 0.69 \\
\end{array}$ & $\begin{array}{c}1.210 \\
\pm 0.034 \\
\end{array}$ & $\begin{array}{c}5.800 \\
\pm 0.291 \\
\end{array}$ & 20 & $\begin{array}{r}7.000 \\
\pm 0.365 \\
\end{array}$ & $\begin{array}{r}93.839 \\
\pm 1.305 \\
\end{array}$ & $\begin{array}{c}1.296 \\
\pm 0.046 \\
\end{array}$ & $\begin{array}{c}5.600 \\
\pm 0.267 \\
\end{array}$ & 20 & $\begin{array}{c}7.300 \\
\pm 0.517 \\
\end{array}$ \\
\hline $\begin{array}{l}\text { Soybean- } \\
\text { Small } \\
\end{array}$ & $\begin{array}{r}98.000 \\
\pm 2.000 \\
\end{array}$ & $\begin{array}{c}0.750 \\
\pm 0.000 \\
\end{array}$ & $\begin{array}{c}4.000 \\
\pm 0.000 \\
\end{array}$ & 3 & $\begin{array}{c}3.000 \\
\pm 0.000 \\
\end{array}$ & $\begin{array}{r}87.500 \\
\pm 4.549 \\
\end{array}$ & $\begin{array}{r}1.175 \\
\pm 0.075 \\
\end{array}$ & $\begin{array}{c}4.000 \\
\pm 0.000 \\
\end{array}$ & 3 & $\begin{array}{c}4.700 \\
\pm 0.300 \\
\end{array}$ \\
\hline Tic-Tac-Toe & $\begin{array}{r}70.138 \\
\pm 1.352 \\
\end{array}$ & $\begin{array}{c}1.424 \\
\pm 0.084 \\
\end{array}$ & $\begin{array}{c}9.200 \\
\pm 0.727 \\
\end{array}$ & 29 & $\begin{array}{r}13.400 \\
\pm 1.275 \\
\end{array}$ & $\begin{array}{r}71.299 \\
\pm 1.448 \\
\end{array}$ & $\begin{array}{c}1.360 \\
\pm 0.106 \\
\end{array}$ & $\begin{array}{c}8.200 \\
\pm 0.772 \\
\end{array}$ & 22 & $\begin{array}{r}11.800 \\
\pm 1.590 \\
\end{array}$ \\
\hline Wine & $\begin{array}{r}83.660 \\
\pm 2.307 \\
\end{array}$ & $\begin{array}{c}0.940 \\
\pm 0.020 \\
\end{array}$ & $\begin{array}{l}11.100 \\
\pm 0.504 \\
\end{array}$ & 23 & $\begin{array}{l}10.500 \\
\pm 0.637 \\
\end{array}$ & $\begin{array}{l}83.824 \\
\pm 3.349 \\
\end{array}$ & $\begin{array}{c}0.882 \\
\pm 0.002 \\
\end{array}$ & $\begin{array}{c}8.500 \\
\pm 0.167 \\
\end{array}$ & 25 & $\begin{array}{c}7.500 \\
\pm 0.167 \\
\end{array}$ \\
\hline
\end{tabular}

TABel III (CONT...) Comparative Performance ANalysis of ANT-Miners

\begin{tabular}{|c|c|c|c|c|c|c|c|c|c|c|}
\hline \multirow[b]{2}{*}{ Data Set } & \multicolumn{5}{|c|}{ cAnt_Miner2 } & \multicolumn{5}{|c|}{ cAnt_MinerPB } \\
\hline & Accuracy & $\begin{array}{c}\text { Terms } \\
\text { per rule }\end{array}$ & $\begin{array}{c}\text { Number } \\
\text { of rules }\end{array}$ & $\begin{array}{r}\text { Tim } \\
\text { (Sec) } \\
\end{array}$ & $\begin{array}{c}\text { Model } \\
\text { size }\end{array}$ & Accuracy & $\begin{array}{c}\text { Terms } \\
\text { per rule }\end{array}$ & $\begin{array}{c}\text { Number } \\
\text { of rules }\end{array}$ & $\begin{array}{l}\text { Time } \\
\text { (Sec) }\end{array}$ & Model size \\
\hline Anneal & $\begin{array}{l}84.582 \\
\pm 1.576 \\
\end{array}$ & $\begin{array}{c}2.050 \\
\pm 0.086\end{array}$ & $\begin{array}{l}11.400 \\
\pm 0.267 \\
\end{array}$ & 283 & $\begin{array}{l}23.500 \\
\pm 1.376 \\
\end{array}$ & $87.847 \pm 0.525$ & $\begin{array}{c}2.686 \\
\pm 0.140 \\
\end{array}$ & $\begin{array}{l}18.100 \\
\pm 0.623 \\
\end{array}$ & 1381 & $\begin{array}{l}48.700 \\
\pm 3.256 \\
\end{array}$ \\
\hline Australian & $\begin{array}{l}85.652 \\
\pm 1.519 \\
\end{array}$ & $\begin{array}{c}1.431 \\
\pm 0.086 \\
\end{array}$ & $\begin{array}{c}7.400 \\
\pm 0.267 \\
\end{array}$ & 64 & $\begin{array}{l}10.700 \\
\pm 0.895 \\
\end{array}$ & $84.928 \pm 1.263$ & $\begin{array}{c}1.675 \\
\pm 0.139 \\
\end{array}$ & $\begin{array}{l}11.500 \\
\pm 0.522 \\
\end{array}$ & 380 & $\begin{array}{l}19.700 \\
\pm 2.231 \\
\end{array}$ \\
\hline Backup & $\begin{array}{l}95.441 \\
\pm 0.530 \\
\end{array}$ & $\begin{array}{c}1.345 \\
\pm 0.059 \\
\end{array}$ & $\begin{array}{c}4.900 \\
\pm 0.100 \\
\end{array}$ & 254 & $\begin{array}{c}6.600 \\
\pm 0.340 \\
\end{array}$ & $95.118 \pm 1.007$ & $\begin{array}{c}1.213 \\
\pm 0.100 \\
\end{array}$ & $\begin{array}{c}5.100 \\
\pm 0.100 \\
\end{array}$ & 423 & $\begin{array}{c}6.200 \\
\pm 0.533 \\
\end{array}$ \\
\hline Breast & $\begin{array}{l}92.133 \\
\pm 1.190 \\
\end{array}$ & $\begin{array}{c}1.018 \\
\pm 0.018 \\
\end{array}$ & $\begin{array}{l}10.600 \\
\pm 0.221 \\
\end{array}$ & 57 & $\begin{array}{l}10.800 \\
\pm 0.327\end{array}$ & $94.416 \pm 0.944$ & $\begin{array}{c}1.058 \\
\pm 0.028 \\
\end{array}$ & $\begin{array}{l}13.000 \\
\pm 0.422 \\
\end{array}$ & 378 & $\begin{array}{l}13.800 \\
\pm 0.680 \\
\end{array}$ \\
\hline Bupa & $\begin{array}{r}66.134 \\
\pm 2.699 \\
\end{array}$ & $\begin{array}{c}1.046 \\
\pm 0.042 \\
\end{array}$ & $\begin{array}{c}7.200 \\
\pm 0.249 \\
\end{array}$ & 17 & $\begin{array}{c}7.600 \\
\pm 0.521 \\
\end{array}$ & $67.832 \pm 2.575$ & $\begin{array}{c}1.311 \\
\pm 0.069 \\
\end{array}$ & $\begin{array}{l}10.500 \\
\pm 0.307 \\
\end{array}$ & 155 & $\begin{array}{l}13.800 \\
\pm 0.879 \\
\end{array}$ \\
\hline Crx & $\begin{array}{l}86.667 \\
\pm 1.076 \\
\end{array}$ & $\begin{array}{c}1.293 \\
\pm 0.054 \\
\end{array}$ & $\begin{array}{c}6.700 \\
\pm 0.153 \\
\end{array}$ & 68 & $\begin{array}{c}8.700 \\
\pm 0.496 \\
\end{array}$ & $85.362 \pm 0.977$ & $\begin{array}{c}1.528 \\
\pm 0.103 \\
\end{array}$ & $\begin{array}{l}11.400 \\
\pm 0.581 \\
\end{array}$ & 409 & $\begin{array}{r}17.800 \\
\pm 1.879 \\
\end{array}$ \\
\hline Diabetes & $\begin{array}{l}68.624 \\
\pm 0.961 \\
\end{array}$ & $\begin{array}{c}1.703 \\
\pm 0.054 \\
\end{array}$ & $\begin{array}{c}8.100 \\
\pm 0.180 \\
\end{array}$ & 27 & $\begin{array}{l}13.800 \\
\pm 0.533 \\
\end{array}$ & $73.305 \pm 1.107$ & $\begin{array}{c}2.479 \\
\pm 0.108 \\
\end{array}$ & $\begin{array}{l}13.400 \\
\pm 0.636 \\
\end{array}$ & 426 & $\begin{array}{l}33.600 \\
\pm 2.553 \\
\end{array}$ \\
\hline German & $\begin{array}{r}67.800 \\
\pm 1.711 \\
\end{array}$ & $\begin{array}{c}1.232 \\
\pm 0.051 \\
\end{array}$ & $\begin{array}{c}8.500 \\
\pm 0.224 \\
\end{array}$ & 97 & $\begin{array}{l}10.500 \\
\pm 0.563 \\
\end{array}$ & $71.700 \pm 2.000$ & $\begin{array}{c}2.647 \\
\pm 0.249 \\
\end{array}$ & $\begin{array}{r}28.100 \\
\pm 1.394 \\
\end{array}$ & 3061 & $\begin{array}{c}77.300 \\
\pm 10.414 \\
\end{array}$ \\
\hline Hepatitis & $\begin{array}{r}64.917 \\
\pm 4.004 \\
\end{array}$ & $\begin{array}{c}1.885 \\
\pm 0.068 \\
\end{array}$ & $\begin{array}{c}4.800 \\
\pm 0.200 \\
\end{array}$ & 62 & $\begin{array}{c}9.100 \\
\pm 0.586 \\
\end{array}$ & $62.625 \pm 3.859$ & $\begin{array}{c}2.116 \\
\pm 0.130 \\
\end{array}$ & $\begin{array}{l}10.600 \\
\pm 0.427 \\
\end{array}$ & 314 & $\begin{array}{r}22.700 \\
\pm 2.039 \\
\end{array}$ \\
\hline Horse-Colic & $\begin{array}{r}85.333 \\
\pm 1.507 \\
\end{array}$ & $\begin{array}{c}1.120 \\
\pm 0.074 \\
\end{array}$ & $\begin{array}{c}5.000 \\
\pm 0.000 \\
\end{array}$ & 41 & $\begin{array}{c}5.600 \\
\pm 0.371 \\
\end{array}$ & $85.667 \pm 1.928$ & $\begin{array}{c}1.438 \\
\pm 0.141 \\
\end{array}$ & $\begin{array}{c}6.800 \\
\pm 0.442 \\
\end{array}$ & 550 & $\begin{array}{r}10.100 \\
\pm 1.449 \\
\end{array}$ \\
\hline House-Vote & $\begin{array}{r}95.618 \\
\pm 1.006 \\
\end{array}$ & $\begin{array}{c}0.795 \\
\pm 0.005 \\
\end{array}$ & $\begin{array}{c}4.900 \\
\pm 0.100 \\
\end{array}$ & 9 & $\begin{array}{c}3.900 \\
\pm 0.100 \\
\end{array}$ & $94.704 \pm 0.919$ & $\begin{array}{c}1.433 \\
\pm 0.079 \\
\end{array}$ & $\begin{array}{c}5.900 \\
\pm 0.100 \\
\end{array}$ & 63 & $\begin{array}{c}8.500 \\
\pm 0.543 \\
\end{array}$ \\
\hline
\end{tabular}


(IJACSA) International Journal of Advanced Computer Science and Applications, Vol. 8, No. 1, 2017

\begin{tabular}{|c|c|c|c|c|c|c|c|c|c|c|}
\hline Hypothyroid & $\begin{array}{r}69.083 \\
\pm 2.919 \\
\end{array}$ & $\begin{array}{c}1.945 \\
\pm 0.084\end{array}$ & $\begin{array}{c}4.600 \\
\pm 0.163 \\
\end{array}$ & 27 & $\begin{array}{c}9.000 \\
\pm 0.596 \\
\end{array}$ & $62.458 \pm 4.397$ & $\begin{array}{c}2.300 \\
\pm 0.226 \\
\end{array}$ & $\begin{array}{l}10.300 \\
\pm 0.335\end{array}$ & 323 & $\begin{array}{r}24.200 \\
\pm 2.951 \\
\end{array}$ \\
\hline Ionosphere & $\begin{array}{r}78.905 \\
\pm 1.503 \\
\end{array}$ & $\begin{array}{c}0.900 \\
\pm 0.017\end{array}$ & $\begin{array}{c}7.900 \\
\pm 0.100 \\
\end{array}$ & 816 & $\begin{array}{c}7.100 \\
\pm 0.100 \\
\end{array}$ & $84.905 \pm 2.252$ & $\begin{array}{c}1.282 \\
\pm 0.050 \\
\end{array}$ & $\begin{array}{l}15.400 \\
\pm 0.476 \\
\end{array}$ & 6347 & $\begin{array}{r}19.900 \\
\pm 1.251 \\
\end{array}$ \\
\hline $\begin{array}{c}\text { New- } \\
\text { Thyroid }\end{array}$ & $\begin{array}{l}86.991 \\
\pm 1.507\end{array}$ & $\begin{array}{c}1.200 \\
\pm 0.082 \\
\end{array}$ & $\begin{array}{c}5.700 \\
\pm 0.153\end{array}$ & 10 & $\begin{array}{c}6.900 \\
\pm 0.586\end{array}$ & $92.532 \pm 1.057$ & $\begin{array}{c}1.058 \\
\pm 0.032 \\
\end{array}$ & $\begin{array}{c}6.500 \\
\pm 0.224 \\
\end{array}$ & 76 & $\begin{array}{c}6.900 \\
\pm 0.379 \\
\end{array}$ \\
\hline $\begin{array}{c}\text { Soybean- } \\
\text { Large }\end{array}$ & $\begin{array}{l}95.441 \\
\pm 0.530\end{array}$ & $\begin{array}{c}1.291 \\
\pm 0.069 \\
\end{array}$ & $\begin{array}{c}6.000 \\
\pm 0.298 \\
\end{array}$ & 87 & $\begin{array}{c}7.900 \\
\pm 0.781 \\
\end{array}$ & $95.140 \pm 1.098$ & $\begin{array}{c}1.427 \\
\pm 0.142 \\
\end{array}$ & $\begin{array}{c}5.500 \\
\pm 0.269\end{array}$ & 353 & $\begin{array}{c}8.100 \\
\pm 1.080 \\
\end{array}$ \\
\hline $\begin{array}{c}\text { Soybean- } \\
\text { Small } \\
\end{array}$ & $\begin{array}{l}91.000 \\
\pm 5.260\end{array}$ & $\begin{array}{c}1.125 \\
\pm 0.067 \\
\end{array}$ & $\begin{array}{c}4.000 \\
\pm 0.000\end{array}$ & 10 & $\begin{array}{c}4.500 \\
\pm 0.269\end{array}$ & $98.000 \pm 2.000$ & $\begin{array}{c}1.150 \\
\pm 0.067 \\
\end{array}$ & $\begin{array}{c}4.000 \\
\pm 0.000 \\
\end{array}$ & 55 & $\begin{array}{c}4.600 \\
\pm 0.267 \\
\end{array}$ \\
\hline Tic-Тас-Тое & $\begin{array}{r}72.132 \\
\pm 0.965 \\
\end{array}$ & $\begin{array}{c}1.187 \\
\pm 0.087 \\
\end{array}$ & $\begin{array}{c}8.300 \\
\pm 0.517 \\
\end{array}$ & 22 & $\begin{array}{l}10.200 \\
\pm 1.209 \\
\end{array}$ & $80.475 \pm 1.328$ & $\begin{array}{c}1.691 \\
\pm 0.178 \\
\end{array}$ & $\begin{array}{l}12.200 \\
\pm 1.200 \\
\end{array}$ & 310 & $\begin{array}{r}22.500 \\
\pm 4.382 \\
\end{array}$ \\
\hline Wine & $\begin{array}{r}84.804 \\
\pm 1.693 \\
\end{array}$ & $\begin{array}{c}0.882 \\
\pm 0.003 \\
\end{array}$ & $\begin{array}{c}8.500 \\
\pm 0.224 \\
\end{array}$ & 44 & $\begin{array}{c}7.500 \\
\pm 0.224 \\
\end{array}$ & $86.536 \pm 1.680$ & $\begin{array}{c}0.894 \\
\pm 0.002 \\
\end{array}$ & $\begin{array}{c}9.500 \\
\pm 0.224 \\
\end{array}$ & 700 & $\begin{array}{c}8.500 \\
\pm 0.224 \\
\end{array}$ \\
\hline
\end{tabular}

\section{Comparative Analysis of Ant-Miners w.r.t Accuracy}

With the critical view of Table IV, we find that the results of cAnt_MinerPB are more promising in terms of accuracy comparisons. The Algorithm "cAnt_MinerPB" is winner 10 times out of 18 and Ant_Miner is 5 times winner and one time withdraws with cAnt_MinerPB. The results shows that the performance of cAnt_MinerPB is promising for the databases where the size of database is larger, number of attributes and number of classes are high.

TABLE IV. COMPARATIVE ANALYSIS OF ANT-MinERS W.R.T ACCURACY

\begin{tabular}{|c|c|c|c|c|}
\hline \multicolumn{5}{|c|}{ Accuracy Comparison } \\
\hline Data Set & Ant_Miner & cAnt_Miner & cAnt_Miner2 & cAnr_MinerPB \\
\hline Anneal & 86.468 & 85.884 & 84.582 & $\mathbf{8 7 . 8 4 7}$ \\
\hline Australian & $\mathbf{8 5 . 6 5 2}$ & 85.362 & $\mathbf{8 5 . 6 5 2}$ & 84.928 \\
\hline Backup & $\mathbf{9 7 . 6 9 9}$ & 94.129 & 95.441 & 95.118 \\
\hline Breast & 92.841 & 92.694 & 92.133 & $\mathbf{9 4 . 4 1 6}$ \\
\hline Bupa & 61.992 & 65.193 & 66.134 & $\mathbf{6 7 . 8 3 2}$ \\
\hline Crx & 85.942 & 85.362 & $\mathbf{8 6 . 6 6 7}$ & 85.362 \\
\hline Diabetes & 69.152 & 68.612 & 68.624 & $\mathbf{7 3 . 3 0 5}$ \\
\hline German & 70.3 & 69 & 67.8 & $\mathbf{7 1 . 7 1 2}$ \\
\hline Hepatitis & $\mathbf{6 7 . 1 6 7}$ & 60 & 64.917 & 62.625 \\
\hline Horse-Colic & $\mathbf{8 7 . 3 3 3}$ & 86.333 & 85.333 & 85.667 \\
\hline House-Vote & 95.624 & $\mathbf{9 5 . 8 6 7}$ & 95.618 & 94.704 \\
\hline Hypothyroid & 67.708 & 64.583 & $\mathbf{6 9 . 0 8 3}$ & 62.458 \\
\hline Ionosphere & 82.643 & 84.056 & 78.905 & $\mathbf{8 4 . 9 0 5}$ \\
\hline $\begin{array}{l}\text { New- } \\
\text { Thyroid }\end{array}$ & 86.039 & 84.978 & 86.991 & $\mathbf{9 2 . 5 3 2}$ \\
\hline $\begin{array}{l}\text { Soybean- } \\
\text { Large }\end{array}$ & $\mathbf{9 7 . 7 2 1}$ & 93.839 & 95.441 & 95.141 \\
\hline $\begin{array}{l}\text { Soybean- } \\
\text { Small }\end{array}$ & $\mathbf{9 8}$ & 87.521 & 91 & $\mathbf{9 8}$ \\
\hline Tic-Tac-Toe & 70.138 & 71.299 & 72.132 & $\mathbf{8 0 . 4 7 5}$ \\
\hline Wine & 83.66 & 83.824 & 84.804 & $\mathbf{8 6 . 5 3 6}$ \\
\hline Average & 82.559 & 81.028 & 81.7365 & $\mathbf{8 3 . 5 3 0}$ \\
\hline
\end{tabular}

\section{Comparative Analysis of Ant-Miners w.r.t Terms per Rule}

The literature study shows that the rule discovering approach is promising if the terms per rule are lesser. The Table $\mathrm{V}$ depicts the comparative performance of the given approaches in terms of terms per rule. The performance of cAnt_Miner and cAnt_Miner2 has the lesser terms per rule with respect to other approaches.
TABLE V. COMPARATIVE ANALYSIS OF ANT-MiNERS W.R.T TERMS PER RULE

\begin{tabular}{|c|c|c|c|c|}
\hline & \multicolumn{4}{|c|}{ Terms per rule } \\
\hline Data Sets & Ant_Miner & cAnt_Miner & cAnt_Miner2 & cAnt_MinerPB \\
\hline Anneal & $\begin{array}{c}1.836 \\
\pm 0.030\end{array}$ & $\begin{array}{c}2.031 \\
\pm 0.043\end{array}$ & $2.050 \pm 0.086$ & $2.686 \pm 0.140$ \\
\hline Australian & $\begin{array}{c}1.404 \\
\pm 0.060\end{array}$ & $\begin{array}{c}1.474 \\
\pm 0.041\end{array}$ & $1.431 \pm 0.086$ & $1.675 \pm 0.139$ \\
\hline Backup & $\begin{array}{c}1.097 \\
\pm 0.053\end{array}$ & $\begin{array}{c}1.180 \\
\pm 0.020\end{array}$ & $1.345 \pm 0.059$ & $1.213 \pm 0.100$ \\
\hline Breast & $\begin{array}{c}1.060 \\
\pm 0.010\end{array}$ & $\begin{array}{c}0.950 \\
\pm 0.017\end{array}$ & $1.018 \pm 0.018$ & $1.058 \pm 0.028$ \\
\hline Bupa & $\begin{array}{c}1.010 \\
\pm 0.010\end{array}$ & $\begin{array}{c}1.000 \\
\pm 0.000\end{array}$ & $1.046 \pm 0.042$ & $1.311 \pm 0.069$ \\
\hline Crx & $\begin{array}{c}1.448 \\
\pm 0.051\end{array}$ & $\begin{array}{c}1.507 \\
\pm 0.058\end{array}$ & $1.293 \pm 0.054$ & $1.528 \pm 0.103$ \\
\hline Diabetes & $\begin{array}{c}1.724 \\
\pm 0.046\end{array}$ & $\begin{array}{c}1.610 \\
\pm 0.039 \\
\end{array}$ & $1.703 \pm 0.054$ & $2.479 \pm 0.108$ \\
\hline German & $\begin{array}{c}1.441 \\
\pm 0.039\end{array}$ & $\begin{array}{c}1.510 \\
\pm 0.065\end{array}$ & $1.232 \pm 0.051$ & $2.647 \pm 0.249$ \\
\hline Hepatitis & $\begin{array}{c}2.048 \\
\pm 0.103\end{array}$ & $\begin{array}{c}1.972 \\
\pm 0.062\end{array}$ & $1.885 \pm 0.068$ & $2.116 \pm 0.130$ \\
\hline Horse-Colic & $\begin{array}{c}1.095 \\
\pm 0.039\end{array}$ & $\begin{array}{c}1.090 \\
\pm 0.049 \\
\end{array}$ & $1.120 \pm 0.074$ & $1.438 \pm 0.141$ \\
\hline House-Vote & $\begin{array}{c}0.905 \\
\pm 0.058\end{array}$ & $\begin{array}{c}0.782 \\
\pm 0.014\end{array}$ & $0.795 \pm 0.005$ & $1.433 \pm 0.079$ \\
\hline Hypothyroid & $\begin{array}{c}2.020 \\
\pm 0.059\end{array}$ & $\begin{array}{c}2.105 \\
\pm 0.081\end{array}$ & $1.945 \pm 0.084$ & $2.300 \pm 0.226$ \\
\hline Ionosphere & $\begin{array}{c}0.980 \\
\pm 0.014\end{array}$ & $\begin{array}{c}1.000 \\
\pm 0.000\end{array}$ & $0.900 \pm 0.017$ & $1.282 \pm 0.050$ \\
\hline $\begin{array}{l}\text { New- } \\
\text { Thyroid }\end{array}$ & $\begin{array}{c}1.240 \\
\pm 0.098\end{array}$ & $\begin{array}{c}1.300 \\
\pm 0.100\end{array}$ & $1.291 \pm 0.069$ & $1.427 \pm 0.142$ \\
\hline $\begin{array}{l}\text { Soybean- } \\
\text { Large }\end{array}$ & $\begin{array}{c}1.210 \\
\pm 0.034\end{array}$ & $\begin{array}{c}1.296 \\
\pm 0.046\end{array}$ & $1.125 \pm 0.067$ & $1.150 \pm 0.067$ \\
\hline $\begin{array}{l}\text { Soybean- } \\
\text { Small }\end{array}$ & $\begin{array}{c}0.750 \\
\pm 0.000\end{array}$ & $\begin{array}{c}1.175 \\
\pm 0.075 \\
\end{array}$ & $1.187 \pm 0.087$ & $1.691 \pm 0.178$ \\
\hline Tic-Тac-Тoe & $\begin{array}{c}1.424 \\
\pm 0.084\end{array}$ & $\begin{array}{c}1.360 \\
\pm 0.106\end{array}$ & $0.882 \pm 0.003$ & $0.894 \pm 0.002$ \\
\hline Wine & $\begin{array}{c}0.940 \\
\pm 0.020\end{array}$ & $\begin{array}{c}0.882 \\
\pm 0.002\end{array}$ & $2.050 \pm 0.086$ & $2.686 \pm 0.140$ \\
\hline
\end{tabular}

N. Comparative Analysis of Ant-Miners w.r.t Number of Rules

The literature study shows that the rule discovering approach is promising if the discovered Number of Rules are lesser for the classification purpose. The Table VI shows the 
performance comparison of the given approaches in terms of Number of Rules discovered. The performance of cAnt_Miner is promising with respect to the other state-of-the-art approaches.

TABLE VI. COMPARATIVE ANALYSIS OF ANT-MiNERS W.R.T NUMBER OF RULES

\begin{tabular}{|c|c|c|c|c|}
\hline & \multicolumn{4}{|c|}{ Number of rules } \\
\hline Data Sets & Ant_Miner & cAnt_Miner & cAnt_Miner2 & cAnt_MinerPB \\
\hline Anneal & $\begin{array}{l}12.300 \\
\pm 0.260 \\
\end{array}$ & $\begin{array}{r}10.980 \\
\pm 0.208 \\
\end{array}$ & $\begin{array}{l}11.400 \\
\pm 0.267 \\
\end{array}$ & $18.100 \pm 0.623$ \\
\hline Australian & $\begin{array}{c}8.300 \\
\pm 0.213\end{array}$ & $\begin{array}{c}6.600 \\
\pm 0.163\end{array}$ & $7.400 \pm 0.267$ & $11.500 \pm 0.522$ \\
\hline Backup & $\begin{array}{c}5.400 \\
\pm 0.163 \\
\end{array}$ & $\begin{array}{c}5.000 \\
\pm 0.000\end{array}$ & $4.900 \pm 0.100$ & $5.100 \pm 0.100$ \\
\hline Breast & $\begin{array}{l}13.500 \\
\pm 0.342 \\
\end{array}$ & $\begin{array}{r}10.300 \\
\pm 0.153 \\
\end{array}$ & $\begin{array}{l}10.600 \\
\pm 0.221 \\
\end{array}$ & $13.000 \pm 0.422$ \\
\hline Bupa & $\begin{array}{c}9.100 \\
\pm 0.100 \\
\end{array}$ & $\begin{array}{c}7.400 \\
\pm 0.163 \\
\end{array}$ & $7.200 \pm 0.249$ & $10.500 \pm 0.307$ \\
\hline Crx & $\begin{array}{c}7.800 \\
\pm 0.249\end{array}$ & $\begin{array}{c}6.300 \\
\pm 0.260\end{array}$ & $6.700 \pm 0.153$ & $11.400 \pm 0.581$ \\
\hline Diabetes & $\begin{array}{c}9.200 \\
\pm 0.200 \\
\end{array}$ & $\begin{array}{c}8.500 \\
\pm 0.224 \\
\end{array}$ & $8.100 \pm 0.180$ & $13.400 \pm 0.636$ \\
\hline German & $\begin{array}{c}9.800 \\
\pm 0.389 \\
\end{array}$ & $\begin{array}{c}8.800 \\
\pm 0.133 \\
\end{array}$ & $8.500 \pm 0.224$ & $28.100 \pm 1.394$ \\
\hline Hepatitis & $\begin{array}{c}5.500 \\
\pm 0.269 \\
\end{array}$ & $\begin{array}{c}4.900 \\
\pm 0.277 \\
\end{array}$ & $4.800 \pm 0.200$ & $10.600 \pm 0.427$ \\
\hline Horse-Colic & $\begin{array}{c}4.400 \\
\pm 0.221 \\
\end{array}$ & \begin{tabular}{|c|}
5.200 \\
\pm 0.133 \\
\end{tabular} & $5.000 \pm 0.000$ & $6.800 \pm 0.442$ \\
\hline House-Vote & $\begin{array}{c}5.300 \\
\pm 0.300 \\
\end{array}$ & $\begin{array}{c}4.700 \\
\pm 0.213 \\
\end{array}$ & $4.900 \pm 0.100$ & $5.900 \pm 0.100$ \\
\hline Hypothyroid & $\begin{array}{c}5.600 \\
\pm 0.163 \\
\end{array}$ & $\begin{array}{c}4.900 \\
\pm 0.100 \\
\end{array}$ & $4.600 \pm 0.163$ & $10.300 \pm 0.335$ \\
\hline Ionosphere & $\begin{array}{l}10.100 \\
\pm 0.233 \\
\end{array}$ & $\begin{array}{c}7.900 \\
\pm 0.100 \\
\end{array}$ & $7.900 \pm 0.100$ & $15.400 \pm 0.476$ \\
\hline $\begin{array}{c}\text { New- } \\
\text { Thyroid }\end{array}$ & $\begin{array}{c}5.300 \\
\pm 0.153 \\
\end{array}$ & $\begin{array}{c}5.000 \\
\pm 0.000 \\
\end{array}$ & $6.000 \pm 0.298$ & $5.500 \pm 0.269$ \\
\hline $\begin{array}{l}\text { Soybean- } \\
\text { Large }\end{array}$ & $\begin{array}{c}5.800 \\
\pm 0.291 \\
\end{array}$ & $\begin{array}{c}5.600 \\
\pm 0.267 \\
\end{array}$ & $4.000 \pm 0.000$ & $4.000 \pm 0.000$ \\
\hline $\begin{array}{l}\text { Soybean- } \\
\text { Small }\end{array}$ & $\begin{array}{c}4.000 \\
\pm 0.000 \\
\end{array}$ & $\begin{array}{c}4.000 \\
\pm 0.000 \\
\end{array}$ & $8.300 \pm 0.517$ & $12.200 \pm 1.200$ \\
\hline Tic-Тас-Toe & $\begin{array}{r}9.200 \\
\pm 0.727 \\
\end{array}$ & $\begin{array}{c}8.200 \\
\pm 0.772 \\
\end{array}$ & $8.500 \pm 0.224$ & $9.500 \pm 0.224$ \\
\hline Wine & $\begin{array}{l}11.100 \\
\pm 0.504 \\
\end{array}$ & $\begin{array}{c}8.500 \\
\pm 0.167 \\
\end{array}$ & $\begin{array}{l}11.400 \\
\pm 0.267 \\
\end{array}$ & $18.100 \pm 0.623$ \\
\hline
\end{tabular}

\section{O. Comparative Analysis of Ant-Miners w.r.t Time}

The time constraint is very important and performance measuring attributes for the rule mining approaches particularly and computational area generally. The algorithmic approach requiring lesser time for the discovery of rules is promising. Here the Table VII shows the performance comparison of the given approaches in terms of time consumption for the rule discovery from the database. The performance of Ant_Miner in terms of "time" is promising with respect to the other state-ofthe-art approaches.
TABLE VII. COMPARATIVE ANALYSIS OF ANT-MINERS W.R.T TIME

\begin{tabular}{|l|l|l|l|l|}
\hline \multicolumn{5}{|l|}{ Time (Sec) } \\
\hline Data Sets & Ant_Miner & cAnt_Miner & cAnt_Miner2 & cAnt_MinerPB \\
\hline Anneal & $\mathbf{8 9}$ & 858 & 283 & 1381 \\
\hline Australian & $\mathbf{3 3}$ & 40 & 64 & 380 \\
\hline Backup & $\mathbf{1 4}$ & 325 & 254 & 423 \\
\hline Breast & $\mathbf{2 8}$ & 30 & 57 & 378 \\
\hline Bupa & 27 & 23 & $\mathbf{1 7}$ & 155 \\
\hline Crx & $\mathbf{4 0}$ & 52 & 68 & 409 \\
\hline Diabetes & 28 & $\mathbf{2 3}$ & 27 & 426 \\
\hline German & 57 & 104 & 97 & 3061 \\
\hline Hepatitis & $\mathbf{4 2}$ & 62 & 62 & 314 \\
\hline Horse-Colic & $\mathbf{1 2}$ & 32 & 41 & 550 \\
\hline House-Vote & 15 & $\mathbf{7}$ & 9 & 63 \\
\hline Hypothyroid & $\mathbf{1 4}$ & 16 & 27 & 323 \\
\hline Ionosphere & $\mathbf{3 7 6}$ & 568 & 816 & 6347 \\
\hline $\begin{array}{l}\text { New- } \\
\text { Thyroid }\end{array}$ & 4 & $\mathbf{3}$ & 87 & 353 \\
\hline $\begin{array}{l}\text { Soybean- } \\
\text { Large }\end{array}$ & 20 & 20 & $\mathbf{1 0}$ & 55 \\
\hline $\begin{array}{l}\text { Soybean- } \\
\text { Small }\end{array}$ & $\mathbf{3}$ & $\mathbf{3}$ & 22 & 310 \\
\hline Tic-Tac-Toe & 29 & $\mathbf{2 2}$ & 44 & 700 \\
\hline Wine & $\mathbf{2 3}$ & 25 & 283 & 1381 \\
\hline
\end{tabular}

\section{P. Comparative Analysis of Ant-Miners w.r.t Model Size}

The literature study shows that the rule discovering approach is promising if the model size generated for the discovery of classification rules is smaller in size. The Table VIII shows the performance comparison of the given approaches in terms of model size. The performance of cAnt_Miner is more promising with respect to the other stateof- the -art approaches.

TABLE VIII. COMPARATIVE ANALysis OF ANT-Miners W.R.T Model SizE

\begin{tabular}{|c|c|c|c|c|}
\hline & \multicolumn{4}{|l|}{ Model size } \\
\hline Data Sets & Ant_Miner & cAnt_Miner & cAnt_Miner2 & cAnt_MinerPB \\
\hline Anneal & $\begin{array}{l}22.600 \\
\pm 0.702\end{array}$ & $\begin{array}{l}22.260 \\
\pm 0.368\end{array}$ & $\begin{array}{l}23.500 \\
\pm 1.376\end{array}$ & $\begin{array}{l}48.700 \\
\pm 3.256\end{array}$ \\
\hline Australian & $\begin{array}{l}11.700 \\
\pm 0.684\end{array}$ & $\begin{array}{l}9.700 \\
\pm 0.260\end{array}$ & $\begin{array}{l}10.700 \\
\pm 0.895\end{array}$ & $\begin{array}{l}19.700 \\
\pm 2.231\end{array}$ \\
\hline Backup & $\begin{array}{l}5.900 \\
\pm 0.277 \\
\end{array}$ & $\begin{array}{l}5.900 \\
\pm 0.100 \\
\end{array}$ & $\begin{array}{l}6.600 \\
\pm 0.340 \\
\end{array}$ & $\begin{array}{l}6.200 \\
\pm 0.533 \\
\end{array}$ \\
\hline Breast & $\begin{array}{r}14.300 \\
\pm 0.367 \\
\end{array}$ & $\begin{array}{l}9.800 \\
\pm 0.291 \\
\end{array}$ & $\begin{array}{r}10.800 \\
\pm 0.327 \\
\end{array}$ & $\begin{array}{c}13.800 \\
\pm 0.680 \\
\end{array}$ \\
\hline Bupa & $\begin{array}{l}9.200 \\
\pm 0.200 \\
\end{array}$ & $\begin{array}{l}7.400 \\
\pm 0.163 \\
\end{array}$ & $\begin{array}{l}7.600 \\
\pm 0.521 \\
\end{array}$ & $\begin{array}{c}13.800 \\
\pm 0.879 \\
\end{array}$ \\
\hline Crx & $\begin{array}{l}11.200 \\
\pm 0.249\end{array}$ & $\begin{array}{l}9.500 \\
\pm 0.543\end{array}$ & $\begin{array}{c}8.700 \\
\pm 0.496\end{array}$ & $\begin{array}{c}17.800 \\
\pm 1.879\end{array}$ \\
\hline Diabetes & $\begin{array}{l}15.900 \\
\pm 0.640 \\
\end{array}$ & $\begin{array}{l}13.700 \\
\pm 0.539 \\
\end{array}$ & $\begin{array}{l}13.800 \\
\pm 0.533 \\
\end{array}$ & $\begin{array}{c}33.600 \\
\pm 2.553 \\
\end{array}$ \\
\hline German & $\begin{array}{l}14.100 \\
\pm 0.640\end{array}$ & $\begin{array}{l}13.300 \\
\pm 0.651\end{array}$ & $\begin{array}{l}10.500 \\
\pm 0.563\end{array}$ & $\begin{array}{l}77.300 \\
\pm 10.414\end{array}$ \\
\hline Hepatitis & $\begin{array}{l}11.200 \\
\pm 0.712 \\
\end{array}$ & $\begin{array}{l}9.600 \\
\pm 0.521 \\
\end{array}$ & $\begin{array}{l}9.100 \\
\pm 0.586 \\
\end{array}$ & $\begin{array}{l}22.700 \\
\pm 2.039 \\
\end{array}$ \\
\hline Horse-Colic & $\begin{array}{l}4.800 \\
\pm 0.249 \\
\end{array}$ & $\begin{array}{l}5.700 \\
\pm 0.367 \\
\end{array}$ & $\begin{array}{l}5.600 \\
\pm 0.371 \\
\end{array}$ & $\begin{array}{r}10.100 \\
\pm 1.449 \\
\end{array}$ \\
\hline House-Vote & $\begin{array}{l}4.900 \\
\pm 0.526 \\
\end{array}$ & $\begin{array}{l}3.700 \\
\pm 0.213 \\
\end{array}$ & $\begin{array}{l}3.900 \\
\pm 0.100 \\
\end{array}$ & $\begin{array}{l}8.500 \\
\pm 0.543 \\
\end{array}$ \\
\hline Hypothyroid & $\begin{array}{l}11.300 \\
\pm 0.448 \\
\end{array}$ & $\begin{array}{l}10.300 \\
\pm 0.423 \\
\end{array}$ & $\begin{array}{l}9.000 \\
\pm 0.596 \\
\end{array}$ & $\begin{array}{c}24.200 \\
\pm 2.951 \\
\end{array}$ \\
\hline Ionosphere & $\begin{array}{l}9.900 \\
\pm 0.277 \\
\end{array}$ & $\begin{array}{l}7.900 \\
\pm 0.100 \\
\end{array}$ & $\begin{array}{l}7.100 \\
\pm 0.100 \\
\end{array}$ & $\begin{array}{r}19.900 \\
\pm 1.251 \\
\end{array}$ \\
\hline $\begin{array}{l}\text { New- } \\
\text { Thyroid }\end{array}$ & $\begin{array}{l}6.500 \\
\pm 0.428 \\
\end{array}$ & $\begin{array}{l}6.500 \\
\pm 0.500 \\
\end{array}$ & $\begin{array}{l}7.900 \\
\pm 0.781 \\
\end{array}$ & $\begin{array}{l}8.100 \\
\pm 1.080 \\
\end{array}$ \\
\hline Soybean- & 7.000 & 7.300 & 4.500 & 4.600 \\
\hline
\end{tabular}




\begin{tabular}{|l|l|l|l|c|}
\hline Large & \pm 0.365 & \pm 0.517 & $\mathbf{\pm 0 . 2 6 9}$ & \pm 0.267 \\
\hline Soybean- & $\mathbf{3 . 0 0 0}$ & 4.700 & 10.200 & 22.500 \\
Small & $\pm \mathbf{0 . 0 0 0}$ & \pm 0.300 & \pm 1.209 & \pm 4.382 \\
\hline \multirow{2}{*}{ Tic-Tac-Toe } & 13.400 & 11.800 & $\mathbf{7 . 5 0 0}$ & 8.500 \\
& \pm 1.275 & \pm 1.590 & $\mathbf{0 . 2 2 4}$ & \pm 0.224 \\
\hline \multirow{2}{*}{ Wine } & 10.500 & $\mathbf{7 . 5 0 0}$ & 23.500 & 48.700 \\
& \pm 0.637 & $\pm \mathbf{0 . 1 6 7}$ & \pm 1.376 & \pm 3.256 \\
\hline
\end{tabular}

\section{CONCLUSION}

This research study provides performance analysis of selective Ant-Miners (Ant-Miner, cAnt_Miner, cAnt_Miner2 and cAnt_MinerPB) for the discovery of classification rule. The comparative performance analysis is performed in terms of accuracy, terms per rule, number of rules, running time and model size discovered by the corresponding rule mining algorithms. The results provides the emerging patterns of performance on the specific data sets depending on the variation in number of attributes, size of the database and number of classes. Myra Tool is used for the performance analysis of Ant_Miners focused in the study. We selected 18 public data sets (available on the UCI repository) for the extensive comparative performance analysis of the Ant_Miners. Our results shows that the number of rules, number of terms per rule, running time and model size discovered by cAnt_MinerPB is higher than other Ant_Miners. This research study contributes in two perspectives; firstly by providing focused survey of Ant Colony Optimization based classification rule mining approaches and secondly by providing extensive performance analysis of Ant_Miners by using larger number of data sets. In future performance of Ant_Miners can be analyzed by using bioinformatics data sets.

\section{ACKNOWLEDGMENT}

This research work is sponsored by the Higher Education Commission (HEC) of Pakistan in the form of Scholarship for the PhD program. We are thankful to HEC Pakistan.

\section{REFERENCES}

[1] E. Noda, A.A. Freitas and H.S. Lopes, "Discovering interesting prediction rules with a genetic algorithm," in Proceedings of 1999 congress on evolutionary computation (CEC' 99), Washington, July 1999, pp. 1322-1329.

[2] D.L.A. Araujo, H.S. Lopes and A.A. Freitas. Rule discovery with a parallel genetic algorithm. Proc. 2000 Genetic and Evolutionary Computation (GECCO-2000) Workshop Program, Las Vegas, NV, USA. July 2000, pp. 89-92.

[3] M.V. Fidelis, H.S. Lopes and A.A. Freitas. Discovering comprehensible classification rules with a genetic algorithm. Proc. Congress on Evolutionary Computation - 2000 (CEC-2000), La Jolla, CA, USA, July/2000, pp. 805-810.

[4] L. Yang, D.H. Widyantoro, T. Ioerger and J. Yen, "An entropy-based adaptive genetic algorithm for learning classification rules," in Proceeding of the 2001 congress on evolutionary computation, Seoul, May 2001, pp. 790-796.

[5] X. Zhongyang, Z. Lei and Z. Yufang, A classification rule mining method using hybrid genetic algorithms, IEEE TENCON, Thailand, 2004.

[6] X. Shi and H. Lei, "A genetic algorithm-based approach for classification rule discovery," in Proceedings of International conference on information management, innovation management and industrial engineering (IEEE), Taipei, Dec 2008, pp. 175-178.

[7] M. Muntean and H. Valean, "Learning classification rules with genetic algorithm,” Communications (COMM), 2010 8th International Conference on, Bucharest, Romania, June 2010, pp. 213-216.
[8] Priyanka Sharma and Saroj, "Discovery of Classification Rules using Distributed Genetic Algorithm”, International Conference on Information and Communication Technologies (ICICT 2014), Procedia Computer Science 46 ( 2015 ), pp. 276 - 284.

[9] Rekha Dahiya and Anshima Singh, "A Survey on Text Mining using Genetic Algorithm", International Journal of innovative Research and Development, Vol.3 , Issue 5, May 2014.

[10] Alberto Cano, Jose Mara Luna, Amelia Zafra, and Sebastian Ventura, "A Classification Module for Genetic Programming Algorithms in JCLEC”, Journal of Machine Learning Research 16 (2015), pp. 491-494.

[11] http://jclec.sourceforge.net/classification.

[12] A.Bharathi and E.Deepankumar, "Survey on Classification Techniques in Data Mining”, International Journal on Recent and Innovation Trends in Computing and Communication ISSN: 2321-8169, Volume: 2 Issue: 7, July 2014.

[13] Rasika P. Ghom and N. R. Chopde, "Survey Paper on Data Mining Using Neural Network", International Journal of Science and Research (IJSR), Volume 4 Issue 3, March 2015.

[14] Chamatkar, A.J. and Butey, "Implementation of Different Data Mining Algorithms with Neural Network", International Conference on Computing Communication Control and Automation (ICCUBEA), 2015.

[15] C.C. Bojarczuk, H.S. Lopes, and A.A. Freitas, "Discovering comprehensible classification rules using Genetic Programming: a case study in a medical domain,” in Proceedings of genetic and evolutionary computation conference (GECCO- 99), 1999, pp. 953-958.

[16] K.C. Tan, A. Tay, T.H. Lee, C.M. Heng, "Mining multiple comprehensible classification rules using genetic programming," in Proceedings of the 2002 congress on evolutionary computation, Honolulu, May 2002, pp.1302-1307.

[17] Chi Zhou, Weimin Xiao, Thomas M. Tirpak and Peter C. Nelson, "Evolving Classification Rules with Gene Expression Programming”, in IEEE Transactions on Evolutionary Computation, Vol.7, 2003.

[18] Anubha Sharma and Nirupama Tiwari, "A Survey of Fuzzy Based Association Rule Mining to Find Co-Occurrence Relationships", IOSR Journal of Computer Engineering (IOSR-JCE) e-ISSN: 2278-0661, pISSN: 2278-8727Volume 16, Issue 1, Ver. 5 (Jan. 2014), pp. 83-87.

[19] R.T. Alves, M.R. Delgado and A.A. Freitas. Knowledge discovery with artificial immune systems for hierarchical multi-label classification of protein functions. In: Proc. 2010 World Congress on Computational Intelligence (WCCI-2010/FUZZ-IEEE-2010), pp. 2098-2105.

[20] K.S.Thirunavukkarasu and S.Sugumaran, "Survey Of Classification Rule Mining Techniques For Identifying Disease Cause And Diagnosis", International Journal of Computer Science and Mobile Computing, IJCSMC, Vol. 2, Issue. 12, December 2013, pp. 229 - 238.

[21] Preeti lata sahu, Aradhana Singh and K.L.Sinha, "A Survey on Data Mining Techniques for Classification of Images”, International Journal of Current Engineering and Scientific Research (Ijcesr), Volume-2, Issue-1, 2015.

[22] Chaitali Vaghela, Nikita Bhatt and Darshana Mistry, "A Survey on Various Classification Techniques for Clinical Decision Support System”, International Journal of Computer Applications (0975 - 8887), Volume 116 - No. 23, April 2015.

[23] Mihir R Patel and Dipak Dabhi, "An Extensive Survey on Association Rule Mining Algorithms", International Journal of Emerging Technology and Advanced Engineering, Volume 5, Issue 1, January 2015.

[24] Y.D. Zhang and L.N. Wu, "A genetic ant colony classifier," in Proceeding of World Congress on Computer Science and Information Engineering, Los Angeles, April 2009, pp. 744 - 748.

[25] Sonal P. Rami and Mahesh H. Panchal, "Comparative Analysis of Variations of Ant-Miner by Varying Input Parameters" , International Journal of Computer Applications (0975 - 8887) Volume 60- No.3, December 2012.

[26] N.N Das and Anjali Saini, "A Survey on Different Algorithms of Association Rule Mining and Ant Colony Optimization”, International Journal of Information Science and Computing 1(1): June, 2014, pp. 4348. 
[27] Vanaja, S. and K. Rameshkumar, "Performance Analysis of Classification Algorithms on Medical Diagnoses-a Survey”, Journal of Computer Science 2015, 11 (1), pp. 30-52.

[28] R.S. Parpinelli, H.S. Lopes and A.A. Freitas. Data Mining with an Ant Colony Optimization Algorithm. IEEE Trans. on Evolutionary Computation, special issue on Ant Colony algorithms, 6(4), Aug. 2002, pp. 321-332.

[29] K. Salama and A.A. Freitas. Learning Bayesian network classifiers using ant colony optimization. Swarm Intelligence, Vol. 7, Issue 2-3, Sep. 2013, pp. 229-254.

[30] A.A. Freitas. Are we really discovering "interesting" knowledge from data? Expert Update (the BCS-SGAI Magazine), Vol. 9, No. 1, Special Issue on the 2nd UK KDD Workshop, autumn 2006, pp. 41-47.

[31] A.A. Freitas. A Review of Evolutionary Algorithms for Data Mining. In: O. Maimon and L. Rokach (Eds.) Soft Computing for Knowledge Discovery and Data Mining, pp. 61-93. Springer, 2007.

[32] R.S. Parpinelli, H.S. Lopes and A.A. Freitas. Data Mining with an Ant Colony Optimization Algorithm. IEEE Trans. on Evolutionary Computation, special issue on Ant Colony algorithms, 6(4), Aug. 2002, pp. 321-332.

[33] J. Smaldon and A.A. Freitas. Improving the interpretability of classification rules in sparse bioinformatics datasets. In: Research and Development in Intelligent Systems XXIII - Proc. of AI-2006, Springer, 2006 pp. 377-381.

[34] E.P. Costa, A.C. Lorena, A.C.P.L.F. Carvalho, and A.A. Freitas. A review of performance evaluation measures for hierarchical classifiers. In: Evaluation Methods for Machine Learning II: papers from the 2007 AAAI Workshop, Vancouver, AAAI Press, 2007, pp. 1-6.

[35] R.S. Parpinelli, H.S. Lopes and A.A. Freitas. An ant colony based system for data mining: applications to medical data. Proc. 2001 Genetic and Evolutionary Computation Conf. (GECCO-2001), Morgan Kaufmann, 2001, pp. 791-798.

[36] T. Karthikeyan and J. Mohana Sundaram, "A Study on Ant Colony Optimization with Association Rule”, International Journal of Advanced Research in Computer Science and Software Engineering, Volume 2, Issue 5, May 2012.

[37] A. Colomi, M. Dorigo, and V. Maniezzo, "Distributed optimization by ant colonies," Proceedings of the 1st European Conference on Artificial Life, 1991, pp.134-142.
[38] M. Dorigo. Optimization, Learning and Natural Algorithms (in Italian). $\mathrm{PhD}$ thesis, Dipartimento di Elettronica, Politecnico di Milano, Milan, Italy, 1992.

[39] Bo Liu , Hussein A.Abbass, Bob McKay, Density_based Heuristic for Rule Discovery with Ant_Miner, The 6th Australia- Japan Joint Workshop on Intelligent and Evolutionary System,2002, page 180-184.

[40] B. Liu, H.A. Abbass, and B. McKay, "Classification rule discovery with ant colony optimization," in Proceedings of IEEE/WIC International Conference on Intelligent Agent Technology, 2003, pp. 83-88.

[41] D. Martens, M. de Backer, R. Haesen, J. Vanthienen, M. Snoeck, and B. Baesens, "Classification with ant colony optimization," IEEE Transactions on Evolutionary Computation, Vol. 11, No. 5. Oct. 2007.

[42] Waseem Shahzad, and Abdul Rauf Baig, "Compatibility as a heuristic for construction of rules by artificial ants," Journal of Circuits, Systems, and Computers, Vol.19, No.1, February 2010, pp. 297-306.

[43] Waseem Shahzad and Abdul Rauf Baig, "Hybrid associative classification algorithm using ant colony optimization," International Journal of Innovative Computing, Information and Control (IJICIC), Vol. 7 No. 12, December 2011, pp. 6815-6826.

[44] Abdul Rauf Baig and Waseem Shahzad, "A correlation based AntMiner for classification rule discovery," Neural Computing and Applications Journal, (in press and available online from Springer website for NCA journal). Springer: ISSN: 0941-0643.

[45] F.E.B. Otero, A.A. Freitas and C.G. Johnson. cAnt-Miner: an ant colony classification algorithm to cope with continuous attributes. In: Ant Colony Optimization and Swarm Intelligence (Proc. ANTS 2008), Lecture Notes in Computer Science 5217, pp. 48-59. Springer, 2008.

[46] P Jin, Y Zhu, K Hu and S Li , "Classification rule mining based on ant colony optimization algorithm”, - Intelligent Control and Automation, 2006 - Springer.

[47] P. S. Shelokar, V. K. Jayaraman, and B. D. Kulkarni, "An Ant Colony Optimization-based Classifier System for Bacterial Growth", Internet Electron. J. Mol. Des. 2004, 3, 572-585, http://www.biochempress.com.

[48] Lichman, M. (2013). UCI Machine Learning Repository [http://archive.ics.uci.edu/ml]. Irvine, CA: University of California, School of Information and Computer Science.

[49] Otero F.E.B.: Ant Colony Optimization Framework, MYRA. https://github.com/febo/myr 